\title{
Evaluasi kecacingan dan gambaran lemak feses kucing dengan gejala diare
}

\author{
Afifah Hasna ${ }^{1}$, Damar P. Kusumarini ${ }^{1}$, Fadhilah A Haq ${ }^{1}$, Arief Purwo Mihardi ${ }^{2,3 *}$, Malni Sovinar ${ }^{3}$, \\ Dinda Septiana Br Tampubolon ${ }^{3}$ \\ ${ }^{1}$ Program Pendidikan Profesi Dokter Hewan, Fakultas Kedokteran Hewan, Institut Pertanian Bogor, Jawa Barat \\ ${ }^{2}$ Departemen Klinik Reproduksi dan Patologi, Fakultas Kedokteran Hewan, Institut Pertanian Bogor, Jawa Barat \\ ${ }^{3}$ Klinik Bobon and Vet, Bogor, Jawa Barat
}

ABSTRAK: Konsistensi dan warna feses kucing yang berubah merupakan indikasi adanya gangguan saluran pencernaan. Kajian ini mengevaluasi telur cacing dan gambaran lemak feses pada kucing yang mengalami diare. Kucing domestik sebanyak 5 ekor mengalami gejala klinis berupa anoreksia, letargi, rambut rontok, serta diare dengan skor feses $2 / 5$ dan $3 / 5$. Pemeriksaan feses dengan metode uji apung menunjukkan adanya telur cacing Toxocara sp., Strongyloides sp., dan Trichuris sp. Pemeriksaan lemak dengan pewarnaan Sudan III menunjukkan 2 ekor kucing mengalami steatorrhea. Kucing didiagnosis mengalami kecacingan dengan prognosis fausta. Terapi yang diberikan berupa sediaan antelmintik tablet.

Kata kunci:

diare, kecacingan, kucing, steatorrhea

\section{- PENDAHULUAN}

Kecacingan atau helminthiasis merupakan kejadian infestasi parasit cacing pada tubuh hewan yang dapat terjadi di saluran pencernaan, saluran pernapasan, dan hati. Kejadian helminthiasis pada kucing sering ditemukan pada saluran pencernaan. Klasifikasi cacing tersebut dibagi menjadi 3 kelompok, yaitu cacing gilig (Nematoda), cacing pita (Cestoda), dan cacing daun atau cacing hati (Trematoda). Helminthiasis dapat terjadi pada kucing yang memiliki kebiasaan berada di lingkungan kotor atau defekasi di tempat-tempat yang memiliki peluang kontaminasi besar, seperti tanah berdebu, lubang pasir, tempat sampah, atau rerumputan yang menjadi tempat siklus hidup cacing (Wahyudi et al. 2017).

Steatorrhea merupakan kejadian peningkatan ekskresi lemak dalam feses. Kejadian ini merupakan gambaran klinis dari malabsorpsi lemak dan terjadi akibat kondisi insufisiensi pankreas eksokrin. Peningkatan kandungan lemak pada feses mengakibatkan produksi feses yang pucat, berbau busuk, dan encer. Pemeriksaan steatorrhea dapat dilakukan pada feses untuk mengetahui adanya kandungan lemak. Pemeriksaan dapat dilakukan secara natif atau menggunakan pewarnaan sudan III (Azer \& Sankararaman 2019). Studi kasus ini dibuat untuk mengevaluasi feses pada kucing dengan gejala diare dengan parameter kondisi kecacingan dan lemak feses.

\section{- KASUS}

Anamnesa dan sinyalemen: Kucing domestik 5 ekor dibawa klien ke klinik Bobon and Vet dengan gejala anoreksia, letargi, rambut rontok, serta diare dengan skor feses $2 / 5$ dan 3/5. Pemeriksaan penunjang: Pemeriksaan telur cacing dengan metode uji apung dan pemeriksaan lemak (undigested \& digested fat) dengan pewarnaan Sudan III menggunakan mikroskop. Diagnosa: kecacingan. Prognosa: fausta. Terapi: antelmintik kombinasi (fenbendazole, praziquantel, dan pyrantel pamoat) tablet $70 \mathrm{mg} / \mathrm{kg}$ BB.

\section{- HASIL DAN PEMBAHASAN}

Diare merupakan salah satu gejala kasus kecacingan pada hewan (Muriana et al. 2018). Hasil pemeriksaan feses terhadap lima ekor kucing dengan gejala diare menunjukkan adanya telur cacing pada 4 ekor kucing dan lemak feses pada 2 ekor kucing (Tabel 1).

\begin{tabular}{|c|c|c|c|c|c|}
\hline \multirow{2}{*}{ Hewan } & \multicolumn{3}{|c|}{ Telur cacing* } & \multirow{2}{*}{$\begin{array}{c}\text { Lemak } \\
\text { netral }\end{array}$} & \multirow{2}{*}{$\begin{array}{r}\text { Lemal } \\
\text { bebas }\end{array}$} \\
\hline & Toxocara & Strongloides & Trichuris & & \\
\hline $30-20$ & - & - & - & - & - \\
\hline $39-20$ & - & + & - & - & - \\
\hline $40-20$ & - & ++ & + & - & + \\
\hline 41-20 & - & +++ & - & + & + \\
\hline 44-20 & ++ & ++ & - & - & - \\
\hline
\end{tabular}

Keterangan: $(-)=$ tidak ditemukan telur/droplet lemak, $(+)=$ ringan, $(++)=$ sedang, $(+++)=$ berat

Telur cacing yang ditemukan yaitu Toxocara sp., Strongyloides sp. dan Trichuris sp. (Gambar 1). Hal ini sesuai dengan pernyataan Bowman (2014), bahwa Toxocara cati, Toxascaris leonina, Dipylidium caninunum, Spirometra mansoni, An-

Diterima: 01-09-2021 | Direvisi: 05-10-2021 | Disetujui: 17-10-2021

(C) 2021 CC-BY-SA. Ini adalah artikel Open Access yang didistribusikan berdasarkan ketentuan dari Creative Commons Attribution ShareAlike 4.0 International License (https://creativecommons.org/licenses/by-sa/4.0/). 
cylostoma tubaeforme, Ancylostoma braziliense, Gnathostoma spinigerum, Strongyloides sp., Taenia taeniaeformis, Capillaria $\mathrm{sp}$., Trichuris sp. dan Physaloptera $\mathrm{sp}$. merupakan beberapa jenis cacing yang dapat ditemukan pada feses kucing.

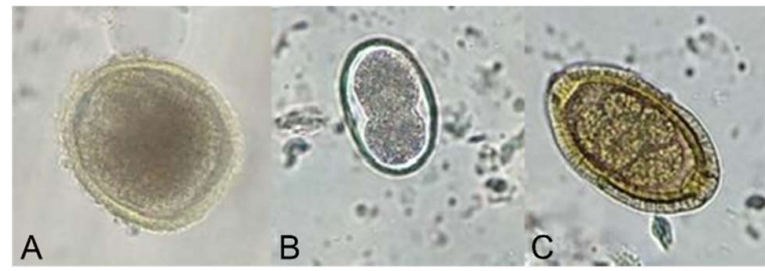

Gambar 1. Telur cacing Toxocara sp. (A), Strongyloides sp. (B), dan Trichuris sp. (C) pada feses kucing.

Infeksi ganda pada kucing 40-20 (Trichuris sp. dan Strongyloides sp.) dan kucing 44-20 (Toxocara sp dan Strongyloides sp.). Berdasarkan Wulcan et al. (2020), Trichuris sp. dapat menembus mukosa usus kecil dan usus besar. Kondisi tersebut menyebabkan kerusakan pada mukosa villi usus sehingga penyerapan lemak bebas di usus menjadi terganggu. Infeksi Trichuris sp. tersebut kemudian mengakibatkan kucing 40-20 mengalami malabsorbsi lemak yang ditandai dengan keberadaan lemak bebas dalam feses (Gambar 2).

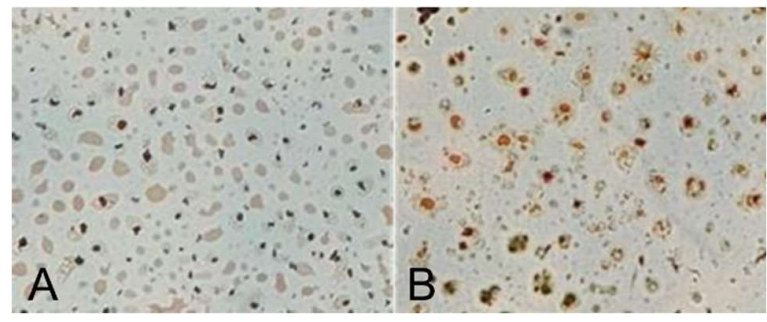

Gambar 2. Feses yang terdapat lemak (A) dan tidak terdapat lemak (B).

Kucing 41-20 juga mengalami infeksi berat akibat Strongyloides sp. yang disertai adanya lemak netral dan lemak bebas pada feses. Lemak netral pada feses menunjukkan adanya gangguan pada proses pencernaan lemak, baik dari pankreas, hati, maupun empedu. Menurut Steiner (2014) menyatakan bahwa gangguan pankreas dapat menyebabkan lemak tidak tercerna dan menyebabkan steatorrhea. Adapun keberadaan lemak bebas menunjukkan lemak mampu dicerna tetapi tidak dapat diaborbsi oleh tubuh.

Berdasarkan Laflamme et al. (2011), malabsorbsi dan maldigesti lemak dapat terjadi akibat adanya kerusakan mukosa atau atrofi villi usus, defisiensi enzim pankreas, atau defisiensi empedu. Studi histologi menunjukkan infeksi Strongyloides sp. dapat menyebabkan atrofi dari vili usus, akumulasi sel limfatik, neutrofil, dan eosinofil pada tempat parasit ditemukan (Gugosyan et al. 2019). Hal inilah yang menyebabkan kucing 41-20 mengalami kecacingan oleh Strongyloides sp. yang disertai dengan steatorrhea.

Terapi yang diberikan yaitu berupa sediaan antelmintik tablet yang mengandung kombinasi zat aktif fenbendazole, praziquantel, dan pyrantel pamoat. Fenbendazole merupakan antelmintik benzimidazole dengan spektrum yang luas
(Schwartz et al. 2000). Praziquantel juga menunjukkan kemampuan sebagai antelmintik berspektrum luas untuk mengatasi cestoda dan trematoda. Pyrantel adalah antelmintik berspektrum luas yang efektif melawan cacing gelang (ascaris), cacing kremi (enterobius), cacing tambang dan trichostrongylus (Arion et al. 2018). Kombinasi fenbendazole, praziquantel, dan pyrantel pamoat tersebut diharapkan dapat mengatasi infeksi cacing yang terjadi pada kucing dalam kajian ini.

\section{- SIMPULAN}

Kucing dengan gejala diare mengalami kecacingan dengan ditemukan telur cacing Toxocara sp., Strongyloides sp. dan Trichuris sp. pada kasus ini. Kecacingan pada kucing disertai steatorrhea dengan adanya lemak pada feses.

\section{- INFORMASI PENULIS}

Penulis untuk Korespondensi

*APM: mihardi.ap@apps.ipb.ac.id

Departemen Klinik, Reproduksi, dan Patologi, Fakultas Kedokteran Hewan, Institut Pertanian Bogor, Jalan Agatis Kampus IPB, Dramaga, Bogor, Jawa Barat, 16680, INDONESIA.

\section{- PUSTAKA ACUAN}

Arion A, Fernández-Varón E, Cárceles CM, Gagyi L, Ognean L. 2018. Pharmacokinetics of praziquantel and pyrantel pamoate combination following oral administration in cats. Journal of feline medicine and surgery. 20(10):900-904.

Azer SA, Sankararaman S. 2020. Steatorrhea. In: StatPearls. StatPearls Publishing, Treasure Island (FL); 2020. PMID: 31082099.

Bowman DD. 2014. Georgis' Parasitology for Veterinarians 10th Edition. Ohio (US): Saunders.

Gugosyan YA, Boyko OO, Brygadyrenko VV. 2019. Morphological variation of four species of Strongyloides (Nematoda, Rhabditida) parasitising various mammal species. Biosystems Diversity. 27(1):85-98

Laflamme DP, Xu H, Long GM. 2011. Effect of diets differing in fat content on chronic diarrhea in cats. Journal of veterinary internal medicine. 25(2):230-235.

Muriana AN, Ridwan Y, Tiuria R, Akbari RA. 2018. Kecacingan pada kucing di Klinik Star Vet Bogor. ARSHI Veterinary Letters. 2(4):6364.

Schwartz RD, Donoghue AR, Baggs RB, Clark T, Partington C. 2000. Evaluation of the safety of fenbendazole in cats. American journal of veterinary research. 61(3):330-332.

Steiner JM. 2014. Exocrine Pancreatic Insufficiency in Cats. World Small Animal Veterinary Association Congress; 16-19 September 2014; Cape Town, South Africa. Cape Town (ZA): World Small Animal Veterinary Association Congress Proceedings. hlm 1-5.

Wahyudi NT, Suwanti LT, Kusnoto, Mumpuni S, Yudaniayanti IS, Mafruchatu M. 2017. Prevalence of helminth eggs in cat feces contaminating public areas in Surabaya. Indonesia journal of tropical and infectious disease. 6(6): 154-159

Wulcan JM, Ketzis JK, Dennis MM. 2020. Typhlitis Associated With Natural Trichuris sp. Infection in Cats. Veterinary pathology. 57(2):266-271. 